\title{
Tidal variation in fish assemblages and trophic structures in tropical Indo-Pacific seagrass beds
}

\author{
Chen-Lu Lee', Yen-Hsun Huang ${ }^{1}$, Chia-Yun Chung ${ }^{1}$ and Hsing-Juh Lin ${ }^{1,2^{*}}$
}

\begin{abstract}
Background: Tidal cycle is an important factor which regularly changes coastal fish assemblages in shallow waters. However, the variations in fish assemblage and trophic structure across tidal cycles in tropical seagrass beds are rarely discussed. We used underwater visual censuses to quantify fish abundance and diversity from the shallow intertidal to the subtidal zone during both flood and ebb tides in seagrass beds surrounding the Dongsha Island, South China Sea. We also recorded fish feeding habits by analyzing stomach contents.

Results: At least 70 fish species were observed in the seagrass beds during the study periods. Fish density and diversity increased with increasing depths, as well as during flood tides. The intertidal areas were characterized by more variation in both fish assemblage and trophic structure than the subtidal areas. A cluster analysis identified six principal feeding groups and invertebrate-feeding carnivores contributed about $70 \%$ of the total fish abundance. The density of herbivores, large-sized carnivores, and piscivores, but not small-sized carnivores, increased during flood tides. In contrast, detritivores decreased in density during flood tides. A heatmap of habitat usage pattern revealed that most fish showed a preference for deeper stations and flood tides. Only a minority of fish showed a preference for shallower stations and ebb tides.

Conclusions: We documented differences in fish assemblage and trophic structure between tides in tropical seagrass beds. Our results suggest that water depth may account for a significant proportion of the variation. The deeper water during flood tides support more space for herbivores and high trophic level carnivores to forage in intertidal meadows. The remaining, non-ebbed seawater columns in the intertidal meadows formed important temporary refuges for fishes during ebb tides. This study offers new information for fish movements over tidal cycles in tropical seagrass beds.
\end{abstract}

Keywords: Coral reef fish; Seagrass; South China Sea; Stomach content analysis; Tidal cycles; Trophic guilds

\section{Background}

Seagrass beds are known as shelters, nurseries, and foraging grounds for numerous marine animals in coastal regions (e.g., Parrish 1989; Duffy 2006). These ecosystem services connect certain coastal habitats via the movements of various nekton and fish species. Therefore, seagrass beds are often considered to serve as crucial ecological connectivity zones in coastal regions. They support abundant fish assemblages across most life history stages and, as such, are critical for the maintenance of coastal fishery resources (Beck et al. 2001; Nagelkerken 2009; Unsworth and Cullen 2010).

\footnotetext{
* Correspondence: hjlin@dragon.nchu.edu.tw

${ }^{1}$ Department of Life Sciences and Research Center for Global Change

Biology, National Chung Hsing University, Taichung 402, Taiwan

${ }^{2}$ Biodiversity Research Center, Academia Sinica, Taipei 115, Taiwan
}

Most seagrass beds are located in shallow waters, where water quality, motion, and depth are all influenced by the tidal rhythm over diel timescales. The tidal cycle is among the most significant factors that controls fish movements, and it can alter assemblage dynamics in shallow waters (Sogard et al. 1989; Gibson 2003). Food availability, shelter quality, or other environmental factors may change over the tidal cycle (Krumme et al. 2008; Krumme 2009). The daily changes in water depth in particular may affect the migration patterns of animals within these shallow, intertidal systems or between other neighboring systems. For instance, during flood tides, the higher water level generally permits more fish from neighboring habitats to enter shallow areas (Robertson and Duke 1990; Krumme 2004). The entrances of these transient fish can lead to an overall increase in fish abundance, and this may alter the trophic

\section{实}

(C) 2014 Lee et al.; licensee Springer. This is an Open Access article distributed under the terms of the Creative Commons Attribution License (http://creativecommons.org/licenses/by/4.0), which permits unrestricted use, distribution, and reproduction in any medium, provided the original work is properly credited. 
structure of the ecosystem on a short-term timescale. On the other hand, the seawater level decline associated with ebb tides may cause many fish to leave the shallow areas to avoid certain environmental constraints, such as increasing temperature or salinity (Ayvazian et al. 1992) or the increased risk of predation (Sogard et al. 1989).

Foraging is likely one of the most important reasons for fish movements over tidal cycles (Krumme 2009). Shallow water vegetation grounds are rich in food sources for many fishes (Nagelkerken and van der Velde 2004; Lugendo et al. 2006; Vonk et al. 2008). These foods not only support the resident fish but may also attract some transient consumers from neighboring systems. Fish may alter their habitat selection as a function of the tidal cycle in seagrass beds (Klumpp and Nichols 1983; Sogard et al. 1989), and this is likely due to the differential distribution of food in response to tidal changes. However, the habitat usage patterns can differ between fish species and across trophic niches (Gibson 2003; Krumme 2004; Reis-Filho et al. 2011). For example, some resident fish may not move significantly beyond their home range, while other transient fish may routinely move between deeper and shallower waters over the course of the tidal cycle (Gibson 1988). Krumme (2009) indicated that the migration behaviors of animals must optimize the benefits of the cost/risk between available habitats.

Seagrass beds of tropical Indo-Pacific region serve as fundamental habitats for many fishes (Dorenbosch et al. 2005; Unsworth et al. 2008a, 2009; Nakamura et al. 2012). Fish assemblages here can be both species-rich and functionally diverse and can demonstrate a complex trophic and habitat structure (Bellwood et al. 2004). The variation in fish abundance in seagrass beds may be driven by both hydrology and landscape structure, especially depth (Dorenbosch et al. 2004; Unsworth et al. 2007a; Pogoreutz et al. 2012). In general, such studies found that the depth changes in the water column that occur in response to the tidal cycle may influence the distribution of different fish. Nevertheless, the variations in fish assemblages and trophic structure across tidal cycles in tropical seagrass beds are rarely discussed.

In this study, we investigated fish assemblage changes between flood and ebb tides within three seagrass beds of different depths at the Dongsha Island, a remote, sparsely populated atoll in the South China Sea. We also collected fish samples for stomach content analysis to understand the trophic niches of the dominant fish species. We aimed to (1) understand the differences in fish assemblage and trophic structure between various depth zones, (2) quantify the differences in fish assemblage and trophic structure, if any, between flood and ebb tides, and (3) uncover the habitat usage patterns of fish occupying different niches in shallow water seagrass beds. We evaluated both trophic and habitat patterns to elucidate the niche categories in seagrass fish assemblages. We hypothesized that the tidal cycle, and more specifically the water depth, would significantly affect fish diversity, abundance, and trophic structure in these tropical, Indo-Pacific seagrass beds.

\section{Methods}

\section{Study site}

Our study was conducted in April, June, and August 2011 at the Dongsha Island (Dongsha Atoll National Park), the South China Sea $\left(20^{\circ} 43^{\prime} 00^{\prime \prime}\right.$ N; $116^{\circ} 42^{\prime} 00^{\prime \prime}$ E) (Figure 1A); this represents the summer wet season, and water temperatures ranged from $27^{\circ} \mathrm{C}$ to $34^{\circ} \mathrm{C}$. This $1.74 \mathrm{~km}^{2}$ coral island is located on the east side of a barrier atoll. Seagrass beds cover a large area $\left(11.85 \mathrm{~km}^{2}\right)$ and typically extend from the lower intertidal to the subtidal zones (depth 0.6 to $5.0 \mathrm{~m}$ ) around the island. The seagrass beds and coral reefs around the Dongsha Island

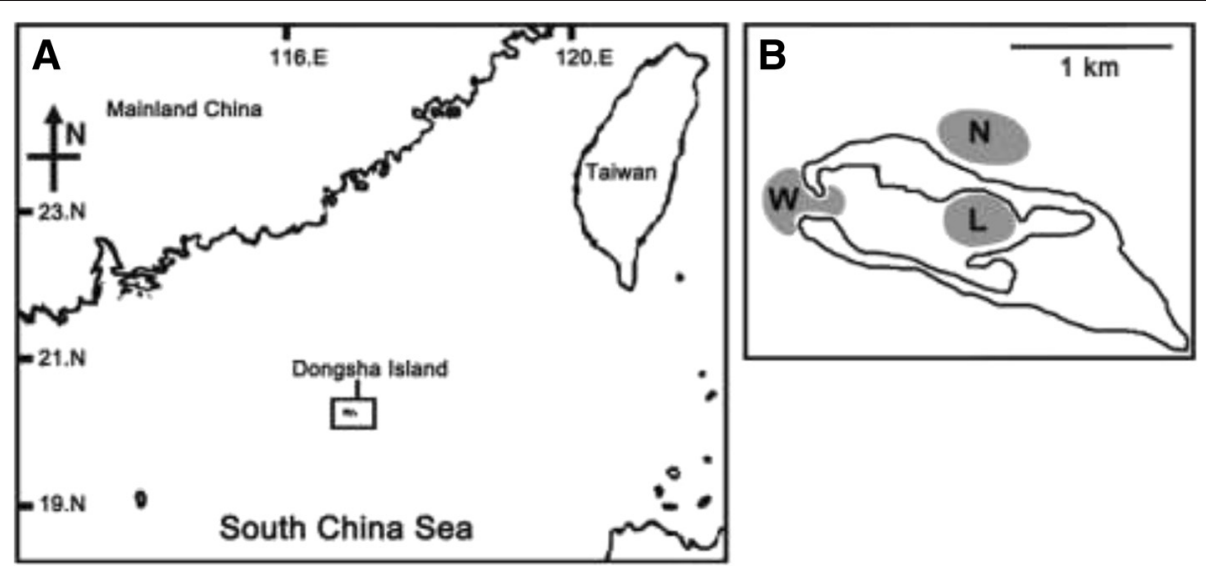

Figure 1 Maps of the study area. (A) The locations of the Dongsha Island within the South China Sea. (B) The locations of the three study stations at the Dongsha Island. The abbreviations for the different stations are L for lagoon shore, W for west tidal flat, and $\mathrm{N}$ for north coast subtidal. 
remain relatively unexploited, and human disturbances have been rare due to the island's isolation and military presence. The main seagrass species around the Dongsha Island are Thalassia hemprichii, Cymodocea rotundata, and Cymodocea serrulata (Lin et al. 2005).

To understand the relationship between depth and fish assemblage in these seagrass beds, we established three study stations characterized by different water depths. The stations were set from the shallow inner lagoon to the outer subtidal zone. First, the lagoon shore station ('L', Figure 1B) was located at the shallow ( 0.1 to $0.3 \mathrm{~m}$ at low tide) shoreline of the inner lagoon. Seagrass beds here cover about $0.4 \mathrm{~km}^{2}$. At this station, most seagrass blades are exposed to the air during ebb tides. Second, the west tidal flat station ('W', Figure 1B) was located at the intertidal flat region (about $0.5 \mathrm{~km}^{2}$ ) around the inlet. Water depth here is also shallow ( 0.2 to $0.5 \mathrm{~m}$ at low tide), though some tidal creeks in the meadows prevent the majority of the seagrass blades from experiencing aerial exposure during low tides. Finally, the north coast subtidal station ('N', Figure 1B) was located at the northern region of the Dongsha Island (about 10 to $50 \mathrm{~m}$ from shore) and served as the deepest station. Seagrass beds here cover about $0.5 \mathrm{~km}^{2}$. The average water depth is more than $1 \mathrm{~m}$, and seagrass are never exposed to the air during ebb tides.

\section{Environmental parameter and fish assemblage surveys}

We deployed three permanent $50-\mathrm{m}$ transects for seagrass surveys at each of the three stations. To exclude possible edge effect, all transects were surveyed only in seagrass meadows to avoid heterogeneity habitats such as coral reefs or bare sandy bottom. To estimate the seagrass cover (\%), five quadrats $(50 \times 50 \mathrm{~cm})$ divided into 25 squares $(10 \times 10 \mathrm{~cm})$ were randomly deployed within each of the nine transects. In each quadrat, the percent cover was assessed from the frequency of mid-point percentage of 6 cover classes of the 25 squares following the methods of Saito and Atobe (1970). The total shoot density was averaged from five randomly selected squares in each of the five quadrats within each transect at each station. In total, 15 seagrass cover and shoot density replicates were recorded at each station in each month. Another five replicate $10 \times 10 \mathrm{~cm}$ quadrats were randomly deployed nearby each transect to collect seagrass shoots for seagrass and epiphyte biomass assessment. The seagrass and epiphytes were dried overnight at $60^{\circ} \mathrm{C}$ to a constant weight before massing.

We used underwater visual censuses (UVC) to quantify the fish abundance and diversity at each station by snorkeling or scuba diving. To understand fish assemblage differences over the tidal cycle, UVCs were conducted within $1 \mathrm{~h}$ of the highest water level of the flood tide and within $1 \mathrm{~h}$ of the lowest water level of the ebb tide during the daytime (0800 to 1600 hours) only to reduce possible diurnal effects. All UVCs were conducted on days characterized by spring tides, in which the largest changes in tidal depth occur. For each survey, six transects $(20 \times 2 \mathrm{~m})$ at each station were separated from each other by at least $5 \mathrm{~m}$ as in Horinouchi et al. (2005). The water temperature, salinity, and depth were recorded at five randomly chosen locations within each of the six transects at each station. Temperature and salinity were recorded by an YSI-556MPS (YSI Inc., Yellow Springs, OH, USA). All transects were placed in the seagrass meadows and allowed to rest on the bottom for $10 \mathrm{~min}$ before initiation of the surveys to prevent interference with the fish. The individual fishes within each transect were identified to species level (when possible) and counted, and their body length (total length [TL], to the $\mathrm{cm}$ level) was recorded. In order to maintain the accuracy of the size determination, estimating fish lengths was practiced prior to the count by estimating the lengths of objects of known size lying on the bottom as in Dorenbosch et al. (2005). All abundance data are represented as density (individuals per $100 \mathrm{~m}^{2}$ ).

\section{Analysis of fish stomach contents}

We used beach seine nets $(6 \mathrm{~m}$ long $\times 1 \mathrm{~m}$ high, $2.5 \mathrm{~mm}$ stretched mesh) or line fishing during daytime flood tides to collect fish samples for stomach contents analysis in randomly chosen locations within each station. We collected 934 fish specimens (195 from L, 254 from $\mathrm{W}$, and 490 from N), representing about 31 species (see Additional file 1). These 31 species were estimated to contribute nearly $91 \%$ of the total fish abundance during the study periods. All specimens were identified to species level, and TL was measured. The fish specimens were dissected, and their stomach contents were collected, immediately fixed in $10 \%$ seawater formalin for further analysis.

In the laboratory, we used a stereomicroscope to examine the stomach contents. Certain morphologically indistinct materials (e.g., algae and detritus) were observed with a light microscope (Zeiss Axioplan2, Göttingen, Germany). All stomach contents were identified to the lowest taxon possible. The composition of the stomach contents was analyzed according to the methods of Hyslop (1980) and presented as volume percentage (V\%). The V\% of each food item in the fish stomachs was visually assessed as follows: stomach contents were compressed on a $1 \times 1 \mathrm{~mm}$ grid slide to a uniform depth of $1 \mathrm{~mm}$, and the areas of each food item were calculated. As part of the identification of the food items, we designated decomposed organic matter with no green pigment or cellulose as detritus (Adams 1976). Fish with empty stomachs were excluded from analyses. 


\section{Data analysis}

A one-way fixed ANOVA model was used to test whether environmental parameters (temperature, salinity, and depth) differed among 6 types of habitats (3 stations $(\mathrm{L}, \mathrm{W}$, and $\mathrm{N}) \times 2$ tides (flood and $\mathrm{ebb})$ ). Seagrass variables (cover, shoot density, biomass, and epiphyte biomass) were compared among three stations using a one-way fixed ANOVA model. Before the analysis, values of seagrass cover were fourth root transformed to conform to normality and homogeneity of variance assumptions (Clarke and Warwick 1994). When significant differences were detected in the model, Tukey's post hoc tests were used to determine individual mean differences $(\alpha=0.05)$.

The stomach contents of all specimens were represented as volume percentages and transformed (fourth root) for subsequent analyses (Clarke and Warwick 1994). The Bray-Curtis similarity index was used to determine the extent of the differences in the composition of stomach contents between different fish species. The similarity data were evaluated with the unweighted pair group mean arithmetic (UPGMA) linking method to identify different feeding groups. The significance of these groups was then tested with analysis of similarity (ANOSIM) (pairwise test). Because no significant differences in food contents were found over the three sampling months for most species (ANOSIM, $p>0.05$ ), we pooled the data from the same species across the 3 months. However, individual fish showing different feeding traits were distinguished as different feeding groups. We used similarity percentage analysis (SIMPER) to represent the dominant food items for each fish species in terms of contribution percentage $(\mathrm{V} \%)$.

Fish assemblage composition data were log-transformed (Clarke and Warwick 1994) to downweigh the influence of dominant species before analysis. A Bray-Curtis similarity analysis was also used to create a resemblance matrix of the log-transformed assemblage data. The resemblance matrixes were also used for non-metric multidimensional scaling (MDS) to show the structure patterns of different stations at different tides. A two-way ANOSIM was used to indicate the assemblage differences between the two tides and three stations.

To examine the abundance of different trophic groups between different stations, fish assemblages from the three stations were compared in terms of the results of the six feeding groups (mentioned below). We excluded $5.35 \%, 1.74 \%$, and $0.98 \%$ of the fish individuals from $\mathrm{L}$, $\mathrm{W}$, and $\mathrm{N}$, respectively, because we could not confirm their feeding habits. Since most assemblage data were heteroscedatic and non-normally distributed, we used three-way permutational multivariate analysis of variance (PERMANOVA, Anderson 2001) to test for differences in fish total density, species richness, and the density of each feeding group between the three stations
(L, W, and $\mathrm{N}$ ), three sampling months (April, June, and August), and two tides (flood and ebb). In this study, effects of station and tide were fixed factors and month effect was a random factor. The Euclidean distance was used to create the resemblance measure, and all data were $\log$ (in total species richness and density) or square root (in density of each feeding group) transformed before analysis (999 permutations).

In order to understand the trophic structure changes and habitat usage patterns of different fish in different assemblages, the log-transformed assemblage data of the predominant fish species of the six trophic groups were used to create a heatmap (Wilkinson and Friendly 2009) in the $\mathrm{R}$ heatmap package ( $\mathrm{R}$ Development Core Team 2012). The heatmap can indicate habitat usage patterns of different fish species at different stations. We separated some fish species of the same trophic groups into different functional groups because they had distinct habitat usage patterns (discussed in the Results section). All of the analyses were performed by $\mathrm{R}$ and PRIMER 6.1.13 and PERMANOVA + 1.0.3 (Clarke and Gorley 2006; Anderson et al. 2008).

\section{Results}

\section{Environmental parameters and fish assemblages}

The average tidal range was 0.6 to $1.0 \mathrm{~m}$ at all study months (Table 1). A significant depth difference was found between stations, and specifically, $\mathrm{N}$ was deeper than the two intertidal stations. Though water temperature was cooler at $\mathrm{N}$ than at the other stations, these differences were not statistically significant (Table 1 ). Salinity was significantly higher at $\mathrm{L}$ during ebb tides. Seagrass cover and density were extensive at all stations, and the cover was typically over $80 \%$. There were no significant differences in seagrass cover, density, and biomass among stations (Table 1); however, the epiphyte biomass at $\mathrm{N}$ was higher than at the other stations.

At least 70 fish species were observed in Dongsha Island's seagrass beds during the study periods. The PERMANOVA results indicated significant interactions in total fish density and species richness between stations and tides (PERMANOVA, $p<0.001$ ), though total density did not significantly differ between survey months (PERMANOVA, $p=0.171$ ). Both total density and species richness were lowest at $\mathrm{L}$, and the species richness was highest at $\mathrm{N}$ (Figure 2A; PERMANOVA, $p<0.001, \mathrm{~N}, \mathrm{~W}>\mathrm{L}$ ). At the two intertidal stations ( $\mathrm{L}$ and $\mathrm{W})$, the total density was higher during flood tides (PERMANOVA, $p<0.001, \mathrm{~F}>\mathrm{E}$, Figure $2 \mathrm{~B}$ ); during this time, the total density increased 1.8- and 3.7-fold over the density during ebb tides at $\mathrm{L}$ and $\mathrm{W}$, respectively. The species richness during flood tides was also 2.8- and 1.2-fold higher than during ebb tides at $\mathrm{L}$ and $\mathrm{W}$, respectively. In contrast, neither total density nor species richness was significantly different between tidal periods at $\mathrm{N}$. 
Table 1 Environmental characteristics of the three stations at the Dongsha Island

\begin{tabular}{|c|c|c|c|c|c|c|c|}
\hline Station & $\begin{array}{l}\text { Water temperature } \\
\left({ }^{\circ} \mathrm{C}\right)\end{array}$ & $\begin{array}{l}\text { Salinity } \\
\text { (psu) }\end{array}$ & $\begin{array}{l}\text { Depth } \\
\text { (m) }\end{array}$ & $\begin{array}{l}\text { Seagrass cover } \\
(\%)\end{array}$ & $\begin{array}{l}\text { Seagrass density } \\
\left(\text { shoots } \mathrm{m}^{-2}\right)\end{array}$ & $\begin{array}{l}\text { Seagrass biomass } \\
\text { (dry weight, } \mathrm{g} \mathrm{m}^{-2} \text { ) }\end{array}$ & $\begin{array}{l}\text { Epiphyte biomass } \\
\text { (dry weight, } \mathrm{g} \mathrm{m}^{-2} \text { ) }\end{array}$ \\
\hline \multirow[t]{2}{*}{ L } & $30.10 \pm 1.97(F)$ & $31.87 \pm 1.11$ a (F) & $0.98 \pm 0.21 b(F)$ & $79.08 \pm 11.31$ & $4523.00 \pm 619.88$ & $892.15 \pm 54.99$ & $0.76 \pm 0.17 a$ \\
\hline & $32.67 \pm 1.45(\mathrm{E})$ & $36.87 \pm 1.79 b(E)$ & $0.21 \pm 0.13$ a (E) & & & & \\
\hline \multirow[t]{2}{*}{ W } & $30.07 \pm 1.49(F)$ & $31.51 \pm 0.95$ a (F) & $1.14 \pm 0.32 b(F)$ & $81.19 \pm 13.56$ & $4017.33 \pm 1204.76$ & $866.72 \pm 141.38$ & $1.10 \pm 0.11 \mathrm{ab}$ \\
\hline & $31.88 \pm 1.19$ (E) & $32.87 \pm 1.67$ a (E) & $0.32 \pm 0.31$ a (E) & & & & \\
\hline \multirow[t]{2}{*}{$N$} & $28.79 \pm 1.11(F)$ & $33.10 \pm 0.37$ a (F) & $2.38 \pm 0.26 c(F)$ & $81.12 \pm 6.85$ & $3975.33 \pm 834.21$ & $1008.12 \pm 84.24$ & $1.74 \pm 0.78 b$ \\
\hline & $29.89 \pm 1.50(\mathrm{E})$ & $32.14 \pm 0.57$ a (E) & $1.53 \pm 0.19 b(E)$ & & & & \\
\hline
\end{tabular}

The abbreviations for the different stations are $\mathrm{L}$ for lagoon shore, $\mathrm{W}$ for west tidal flat, and $\mathrm{N}$ for north coast (subtidal). The abbreviations for the tides are $\mathrm{F}$ for flood tide and $\mathrm{E}$ for ebb tide. Values represent mean \pm standard deviation, and letters adjacent to values in certain columns denote Tukey's post hoc differences $(p<0.05)$ when an overall difference was detected in the ANOVA model.

The MDS plots (Figure 2C) revealed that fish assemblages varied by stations and tides. Fish assemblages were significantly distinct between the three stations (ANOSIM, $p<0.001$ ). The assemblages of $\mathrm{N}$ showed no obvious differences between tides (ANOSIM, $p=0.61$ ). However, the fish assemblages of $\mathrm{W}$ and $\mathrm{L}$ were significantly different between flood and ebb tides (ANOSIM, $p<0.001$ ).

\section{Trophic groups in seagrass fish assemblages}

Twenty major food categories (Table 2) were identified in the stomach content analysis, and a cluster analysis (Figure 3) identified six principal feeding groups at 25\% similarity (ANOSIM, $p<0.001$ ). There were two groups of herbivores; the first group consisted of the algal herbivores (Figure 3, 'AL') and included Siganus spinus, Acanthurus xanthopterus, and Dischistodus prosopotaenia. They fed mostly on filamentous epiphytes. $D$. prosopotaenia demonstrated an ontogenetic dietary change in which specimens ate copepods when $<4$ to $5 \mathrm{~cm}$ in TL, switching to filamentous epiphytes once growing beyond this size. The second herbivore group included two species, Leptoscarus vaigiensis and Hemiramphus far, that mainly consumed seagrass leaves (Figure 3, 'SG'). L. vaigiensis was the most dominant seagrass herbivore at all stations (constituting $>95 \%$ of the abundance of this feeding group), while observations of $H$. far were relatively rare. L. vaigiensis also demonstrated an ontogenetic dietary change in which they fed primarily on detritus, epiphytes, or even copepods when $<7 \mathrm{~cm}$ in TL, then switching to almost exclusively seagrass once larger than this size. The algal and seagrass herbivores constituted about $9.76 \% \pm 1.85 \%$ (average across all three stations \pm standard error) and $9.49 \% \pm 3.10 \%$, respectively, of the total fish abundance in the Dongsha Island's seagrass beds.

Species of the Mugilidae family were found to feed on particulate organic matter (POM) and were the only fish belonging to the detritivorous group (Figure 3, 'DT'). As such, detritivores were relatively rare in our results and only contributed about $3.35 \% \pm 3.39 \%$ of the total fish abundance in the seagrass beds of the Dongsha Island.

Most fish species observed were carnivorous and fed primarily on invertebrates. These invertebrate-feeding carnivores contributed about $70 \%$ of the total fish abundance in the Donghsa Island's seagrass beds. We divided them into two groups since their food preferences were distinct. We assigned fourteen fish species into the 'small carnivores' group (Figure 3, 'SC'), since they fed mostly on small crustaceans, especially copepods, amphipods, and tanaids. Some dipterid insects were found in the stomachs of Atherion elymus. Members of this group included many small-sized $(\mathrm{TL}<8 \mathrm{~cm})$ species, and small labrids (mostly Stethojulis strigiventer and Halichoeres trimaculatus) constituted about $30 \%$ to $60 \%$ of total abundance of this group. The small-sized $(\mathrm{TL}<5$ to $6 \mathrm{~cm})$ Lethrinus spp. and Lutjanus fulviflamma specimens also belonged to this group. The small carnivores constituted $44.36 \pm 6.60 \%$ of the total fish abundance and were the most dominant feeding groups in the Dongsha Island's seagrass beds.

The 'large carnivores' group (Figure 3, 'LC') fed mainly on hard-shelled invertebrates. Decapods, including Palaemonidae, Penaeidae, Majidae, and Portunidae species, were the most important food sources for them (contributing to about $50 \%$ to $90 \%$ of their stomach contents). Their body sizes were mostly larger than those of the small carnivores groups on average $(\mathrm{TL}>10 \mathrm{~cm})$. We assigned eight fish species into this group. The Lethrinus spp. was the most dominant large carnivorous fish species, constituting $>70 \%$ of the total abundance of this group at most stations. We found that Lethrinus spp. and $L$. fulviflamma changed their diet from small crustaceans to decapods when their body size exceeded about 5 to $6 \mathrm{~cm}$. The large carnivores contributed $26.69 \% \pm 5.11 \%$ of the total fish abundance in the Dongsha Island's seagrass beds.

About six piscivorous fish species were found in our results (Figure 3, 'PS'). Cheilio inermis (TL 4 to $10 \mathrm{~cm}$ ) and small Sphyraena barracuda (TL 4 to $8 \mathrm{~cm}$ ) fed on 

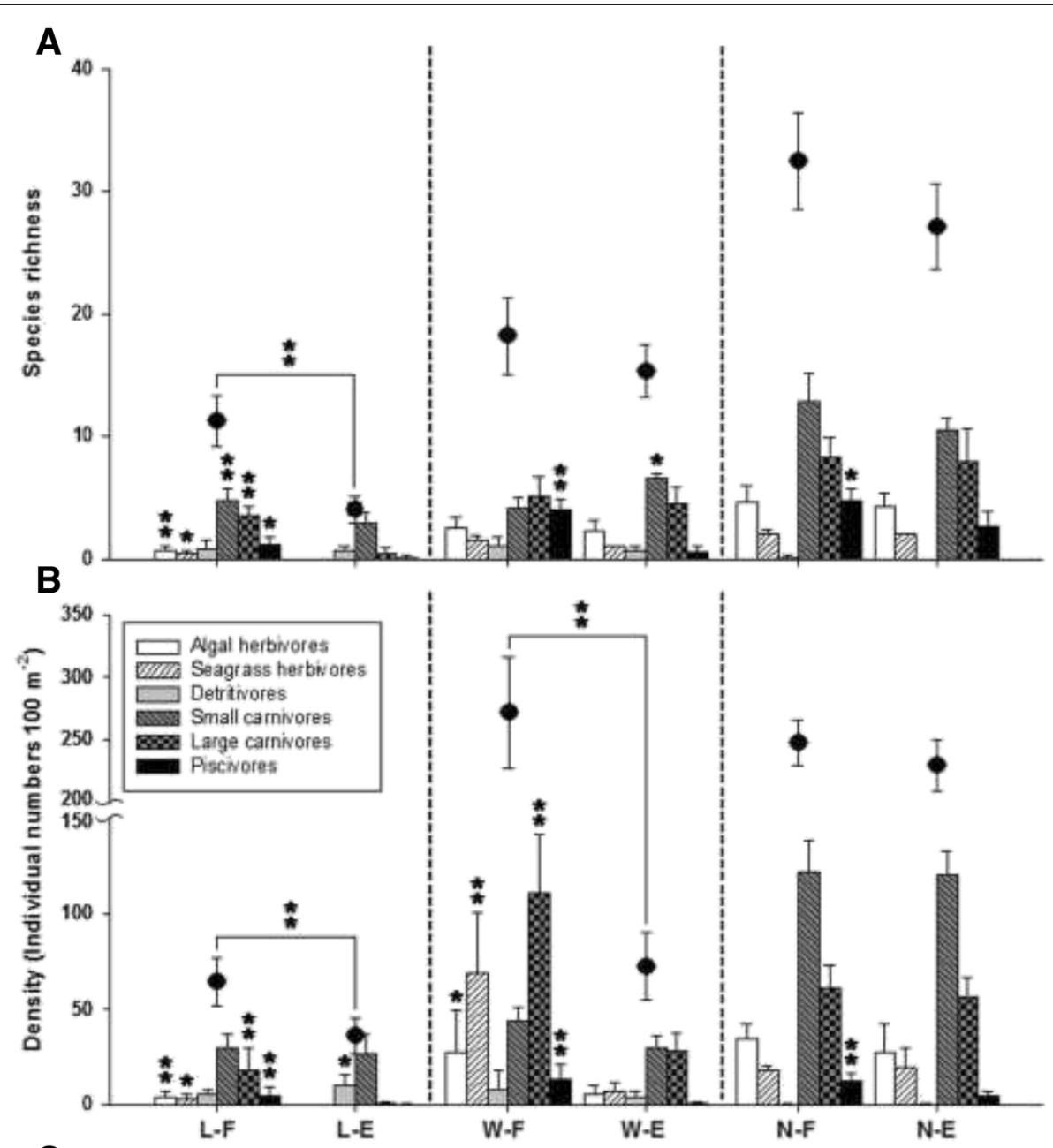

C

Station-Tide

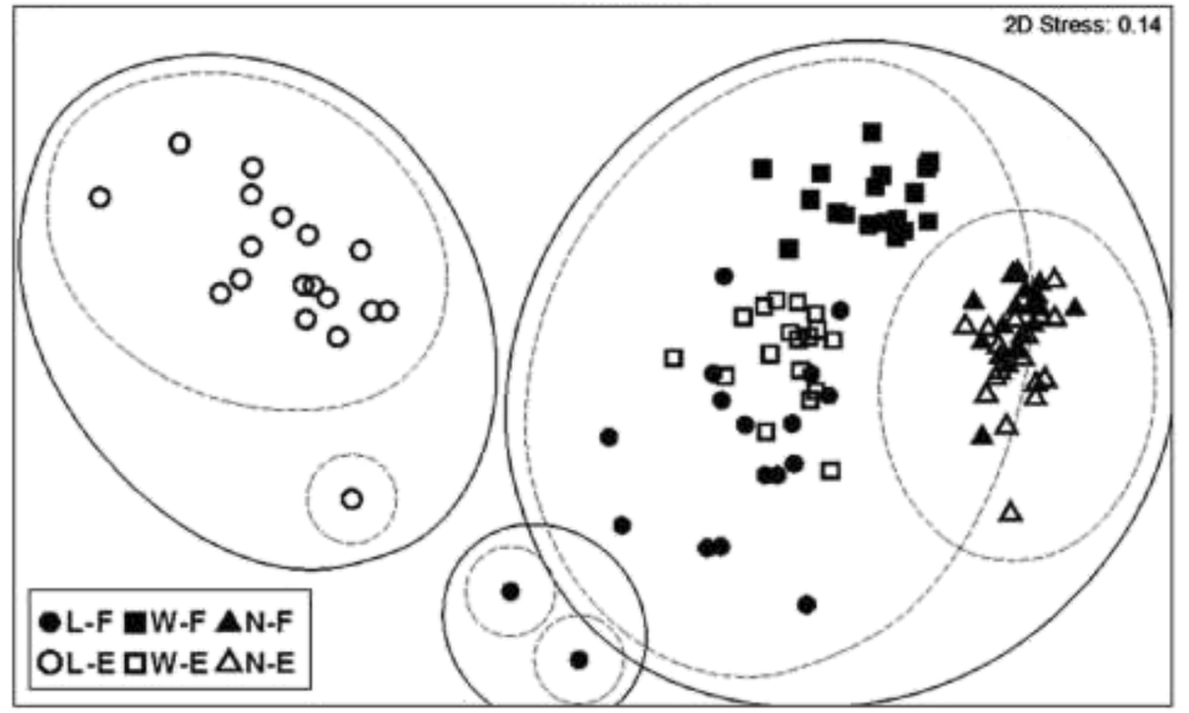

Figure 2 (See legend on next page.) 
(See figure on previous page.)

Figure $\mathbf{2}$ Characteristics of the fish assemblages at the three stations of the Dongsha Island. Values are mean ( \pm standard error) in fish (A) species richness and (B) density of different feeding groups. Black circles (mean \pm standard error) represent the (A) total species richness and (B) total density at each sample station: lagoon shore $(L)$, west tidal flat $(\mathrm{W})$, and north coast subtidal $(\mathrm{N})$ for each of the two tidal periods, flood (F) and ebb (E) tide. * and ${ }^{* *}$ represent significant differences ( $p<0.05$ and $p<0.005$, respectively) between the two tidal periods. (C) The multidimensional scaling (MDS) ordination showing different fish assemblages between three stations and two tidal periods. The solid and dashed line circles represent $20 \%$ and $40 \%$ level similarity, respectively.

fish larvae or decapods. Other species were characterized by larger body sizes $(>15 \mathrm{~cm})$ such as Tylosurus crocodilus, Caranx melampygus, Carangoides spp., and large S. barracuda. They fed mostly on mugilid or atherinid fish. Another piscivore, Negaprion acutidens, fed widely on mugilids, scarids, lethrinids, and lutjanids. The piscivorous fish constituted $3.40 \% \pm 0.85 \%$ of the total fish abundance in the Dongsha Island's seagrass beds.

\section{Species and trophic structure changes across depths and tides}

The density of some feeding groups differed between stations and tides (Figure 2B, Table 3). The two herbivorous (AL and SG), the large carnivorous (LC), and the piscivorous groups (PS) were characterized by higher densities at $\mathrm{W}$ and $\mathrm{N}$ relative to L (PERMANOVA, $p<0.001, \mathrm{~W}, \mathrm{~N}>$ $\mathrm{L}$ ), as well as during flood tides (PERMANOVA, $p<0.005$,

Table 2 The $\mathbf{2 0}$ major food categories of the stomach content analyses and their abbreviations

\begin{tabular}{|c|c|c|}
\hline Classification & Subdivision & Abbreviation \\
\hline \multirow[t]{3}{*}{ Chordata } & Fish & $\mathrm{Fi}$ \\
\hline & Fish larvae & LV \\
\hline & Tunicates & $\mathrm{Tu}$ \\
\hline Echinodermata & Echinoids & Ec \\
\hline \multirow[t]{9}{*}{ Arthropoda } & Decapods & De \\
\hline & Cumaceids & $\mathrm{Cu}$ \\
\hline & Tanaids & $\mathrm{Ta}$ \\
\hline & Copepods & Co \\
\hline & Gammaridean amphipods & Am \\
\hline & Ostracods & Os \\
\hline & Isopods & Is \\
\hline & Mysids & My \\
\hline & Insects (mostly dipterids) & $\ln$ \\
\hline Annelida & Polychaetes & Po \\
\hline \multirow[t]{2}{*}{ Mollusca } & Gastropods & $\mathrm{Ga}$ \\
\hline & Bivalves & $\mathrm{Bi}$ \\
\hline \multirow[t]{3}{*}{ Plantae } & Filamentous algae & $\mathrm{Fa}$ \\
\hline & Fleshy Macroalgae & $\mathrm{Ma}$ \\
\hline & Seagrass & $\mathrm{Sg}$ \\
\hline Detritus & Detritus & Dt \\
\hline
\end{tabular}

Of the fish collected in the seagrass beds at the Dongsha Island.
F $>$ E). The densities of these groups showed high variation between tides at the two intertidal stations (W and L). The densities of these groups decreased to nearly zero during ebb tides at L, whereas members of the two herbivorous and large carnivorous groups were still present at about 10 to 30 per $100 \mathrm{~m}^{2}$ at $\mathrm{W}$ during ebb tides (Figure 2B). In contrast, the small carnivores group (SC) did not demonstrate significant density differences between tides (PERMANOVA, $p=0.314$ ), though they were found at higher densities at the subtidal station (PERMANOVA, $p<0.001$, $\mathrm{N}>\mathrm{W}, \mathrm{L}$ ). The detritivorous mugilids (DT) showed the opposite habitat usage pattern from the other feeding groups. These mugilids were more abundant at the two intertidal stations than the subtidal station (PERMANOVA, $p<$ $0.001, L, W>N$ ), and they were also present at higher densities during ebb tides (PERMANOVA, $p<0.05, \mathrm{E}>\mathrm{F}$ ).

A heatmap (Figure 4) revealed the habitat usage patterns of different fish at the three stations during the two tidal periods. Most fish (group A) showed a preference for deeper waters (i.e., the subtidal zone and/or during flood tides). Many dominant carnivorous (e.g., Lethrinus harak and Lethrinus fulviflamma), herbivorous (e.g., L. vaigiensis), and one piscivorous (C. inermis) fish were more abundant in subtidal meadows or during flood tides (Figure 4, type I). Most large piscivorous fish (i.e., carangids, $T$. crocodilus, $N$. acutidens, and large $S$. barracuda) and two herbivorous fish (S. spinus and $H$. far) demonstrated transient usage patterns. They were found only during flood tides and were almost absent during ebb tides at the two intertidal stations (Figure 4, type II). Moreover, seven fish species specifically preferred subtidal zones and were nearly absent at the two intertidal stations (Figure 4, type III). In contrast, one piscivore (small S. barracuda), three carnivores (A. elymus, Gerres oyena, and Gymnothorax richardsonii), and the mugilids showed a preference for the two intertidal stations (Figure 4, Group B). Most of these species could be found at the two intertidal stations during either tide (Figure 4, type IV). A. elymus showed a preference for $\mathrm{L}$, and they were only present at high densities during ebb tides (Figure 4, type V).

Although some fish species demonstrated ontogenetic dietary changes, most of these fish did not have significantly different habitat usage patterns at different body sizes. We only found that S. barracuda changed from 


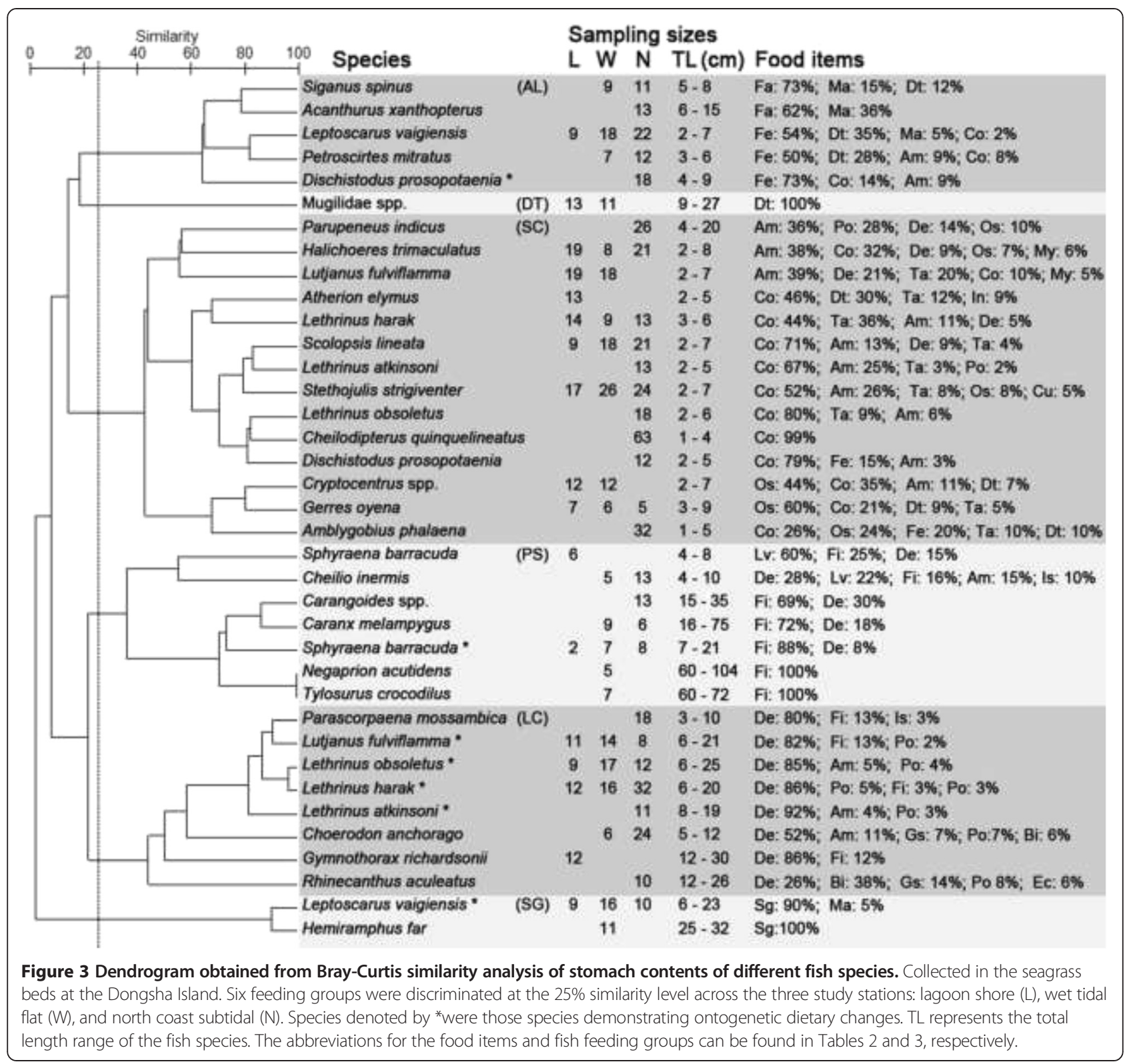

residents of intertidal areas, to transients of seagrass meadows once their body size exceeded $8 \mathrm{~cm}$ in TL.

\section{Discussion}

We documented distinct fish assemblages at different points in the tidal cycle around the Dongsha Island. Fish density and richness were both higher at the deeper subtidal station, as well as during flood tides. We also documented variation in the density of different trophic groups over the tidal cycle. Many trophic groups were overrepresented at greater depths, including most herbivores, large carnivores, and piscivores (Figure 4, Group A). Indeed, numerous studies have documented increases in fish densities during flood tides (Kneib and Wagner 1994; Unsworth et al. 2007a). Generally, the deeper water can support more fish abundance by both retaining more space and serving as a more stable environment for larger sized or pelagic fish (Pogoreutz et al. 2012). Lower water levels may also restrict movements, or cause stranding, both of which could affect predation (Sogard et al. 1989). In fact, we found many shore birds (especially egrets) feeding at the intertidal stations during ebb tides, a similar observation also made by Unsworth et al. (2007a) in the Hoga Island, Indonesia.

Seawater quality could also have driven fish depth preferences in this study. Station L is a shallow station characterized by poor circulation, as it is far from the only lagoonal channel. Seawater temperature here can reach $35^{\circ} \mathrm{C}$, and salinity can reach 39 psu during ebb tides in summer, representing a poor quality habitat for 
Table 3 Summary of the results from mixed-model PERMANOVAs

\begin{tabular}{|c|c|c|c|c|c|c|c|c|c|c|}
\hline \multirow[b]{2}{*}{ Source } & \multirow[b]{2}{*}{$d f$} & \multicolumn{3}{|c|}{ Algal herbivore (AL) } & \multicolumn{3}{|c|}{ Seagrass herbivore (SG) } & \multicolumn{3}{|c|}{ Detritivore (DT) } \\
\hline & & MS & Pseudo F & $p$ value ${ }^{*}$ & $\overline{M S}$ & Pseudo F & $p$ value* & MS & Pseudo F & $p$ value ${ }^{*}$ \\
\hline Site (S) & 2 & 58.42 & 51.26 & 0.001 & 850.07 & 9.44 & 0.001 & 9.03 & 11.53 & 0.001 \\
\hline Month (M) & 2 & 0.19 & 0.17 & 0.849 & 13.13 & 0.15 & 0.869 & 0.28 & 0.36 & 0.710 \\
\hline Tide (T) & 1 & 18.57 & 16.29 & 0.001 & 848.07 & 9.42 & 0.003 & 5.41 & 6.90 & 0.019 \\
\hline$S \times M$ & 4 & 0.35 & 0.30 & 0.887 & 52.07 & 0.58 & 0.707 & 0.41 & 0.52 & 0.722 \\
\hline$S \times T$ & 2 & 8.62 & 7.56 & 0.004 & 392.52 & 4.36 & 0.009 & 15.45 & 19.72 & 0.001 \\
\hline$M \times T$ & 2 & 0.31 & 0.27 & 0.772 & 14.69 & 0.16 & 0.871 & 0.69 & 0.88 & 0.444 \\
\hline $\mathrm{S} \times \mathrm{M} \times \mathrm{T}$ & 4 & 1.11 & 0.97 & 0.453 & 73.46 & 0.82 & 0.561 & 0.66 & 0.84 & 0.495 \\
\hline Residual & 36 & \multicolumn{3}{|l|}{1.14} & \multicolumn{3}{|l|}{90.02} & \multicolumn{3}{|l|}{0.78} \\
\hline \multirow[t]{2}{*}{ Total } & \multicolumn{10}{|l|}{53} \\
\hline & & \multicolumn{3}{|c|}{ Small carnivore (SC) } & \multicolumn{3}{|c|}{ Large carnivore (LC) } & \multicolumn{3}{|c|}{ Piscivore (PS) } \\
\hline Source & $d f$ & $\overline{M S}$ & Pseudo F & $p$ value ${ }^{*}$ & MS & Pseudo F & $p$ value* & MS & Pseudo F & $p$ value* \\
\hline Site (S) & 2 & 29554 & 166.2 & 0.001 & 189.9 & 171.3 & 0.001 & 40.16 & 78.12 & 0.001 \\
\hline Month (M) & 2 & 61.56 & 0.346 & 0.709 & 0.761 & 0.686 & 0.542 & 0.47 & 0.92 & 0.419 \\
\hline Tide (T) & 1 & 188.9 & 1.063 & 0.314 & 185.4 & 167.2 & 0.001 & 10.14 & 19.73 & 0.003 \\
\hline$S \times M$ & 4 & 21.28 & 0.12 & 0.981 & 0.533 & 0.481 & 0.743 & 0.51 & 0.98 & 0.448 \\
\hline$S \times T$ & 2 & 482 & 2.711 & 0.071 & 38.98 & 35.16 & 0.001 & 1.32 & 2.58 & 0.103 \\
\hline$M \times T$ & 2 & 9.852 & 0.055 & 0.944 & 1.233 & 1.112 & 0.339 & 0.21 & 0.42 & 0.661 \\
\hline $\mathrm{S} \times \mathrm{M} \times \mathrm{T}$ & 4 & 209.8 & 1.18 & 0.332 & 0.476 & 0.43 & 0.801 & 0.38 & 0.73 & 0.549 \\
\hline Residual & 36 & 177.8 & & & 1.109 & & & 0.51 & & \\
\hline Total & 53 & & & & & & & & & \\
\hline
\end{tabular}

On the densities of six fish feeding groups collected in the seagrass beds at the Dongsha Island. Statistically significant values $(p<0.05)$ are highlighted in bold font. ${ }^{*} p$ values are all permutational.

many fish at such times. Such extreme heating of shallow water habitats has been found to be detrimental to fish physiology in other studies and may explain why most fish temporarily entered intertidal seagrass meadows only during flood tides (Krumme 2009). Hence, we propose that the quality and quantity of the retained seawater are critical factors that affect the fish assemblage changes in shallow water seagrass beds over the tidal cycle. Seagrass meadows at the subtidal $\mathrm{N}$ were never exposed to the air because of the deeper waters associated with this station. The temperature and salinity here were also more stable than those of the two intertidal stations. This may explain why the fish assemblage composition at the subtidal $\mathrm{N}$ did not differ significantly between tides, while the two intertidal stations had more variation in fish density and composition over the tidal cycle. Moreover, more fish species were found at the subtidal station and some fish only inhabited the subtidal zone. They might prefer the relatively more stable environment found at $\mathrm{N}$, which varied little over the tidal cycle.

Deeper water provides more space for large piscivorous fish in seagrass beds. Most large piscivores such as $T$. crocodilus, carangids, and lemon sharks (N. acutidens) were all transient visitors of seagrass beds, and their number increased significantly with water depth. Their body lengths may have limited their movements to where they could only enter the intertidal zones during flood tides. The movements of their prey may also have influenced the movements of these transient piscivores. Hoeinghaus et al. (2003) noted that piscivores are highly active during post-flooding periods because they can more easily attack fish that become trapped in shallow waters at such times. Unsworth et al. (2007a) also found that $C$. melampygus was only found during high tides in shallow regions. We did note that many carangids were more active in the intertidal waters when the water reached its highest levels of the day. Moreover, we also found many juvenile lemon sharks (TL, 0.7 to $1.2 \mathrm{~m}$ ) chasing other fish in the intertidal zone, and their density was especially high at W during flood tides. They foraged mostly in seagrass meadows to catch parrotfish, emperors, or snappers. Young lemon sharks prefer shallow lagoons as feeding grounds, whereas adults spend more time in deeper reefs (Last and Stevens 2009). Our findings clearly show that juveniles prefer shallow areas at the Dongsha Island, whereas large individuals (TL > $2 \mathrm{~m}$ ) only occur in the subtidal zones. We believe that the shallow and well-canopied seagrass beds at the Dongsha Island serve as critical juvenile foraging grounds for these sharks. 


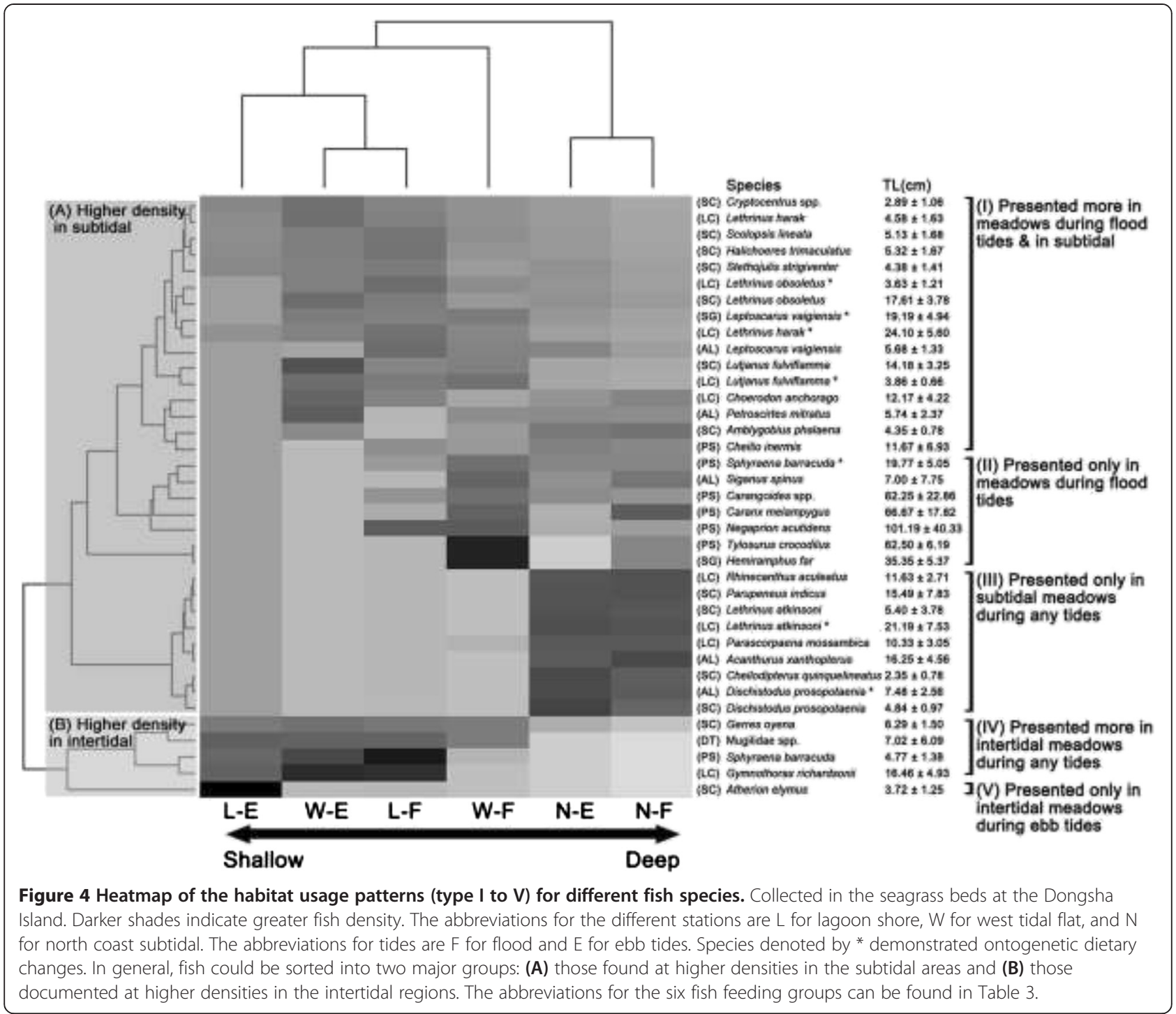

As in seagrass beds observed in prior studies (e.g., Nakamura et al. 2003; Lugendo et al. 2006; Nagelkerken et al. 2006), most fish in the Dongsha Island's seagrass beds were invertebrate-feeding carnivores. Dominant large carnivores, including Lethrinus spp. and L. fulviflamma fed mainly on shelled invertebrates, especially decapods. Many juveniles of these species feed mainly on small crustaceans until they reach a certain body size, at which their foraging abilities and nutrient requirements change (Nakamura et al. 2003; Kamukuru and Mgaya 2004). The lethrinids and lutjanids utilize shallow seagrass/mangrove canopies as nurseries or feeding grounds in many Indo-Pacific regions (Unsworth et al. 2008b, 2009; Kimirei et al. 2011; Nakamura et al. 2010, 2012; Berkström et al. 2013). We found their densities to increase at the intertidal stations during flood tides, especially at W. Previous researchers have found that some decapods move into shallow areas during flood tides, and some carnivorous fish may follow them at these times for foraging (Klumpp and Nichols 1983). However, the density of small carnivores did not significantly differ between tides. Some studies have shown that small fish may not move long distances (Kneib and Wagner 1994). Many small carnivores are small sized and highly adapted to life in intertidal waters. Small labrids such as $H$. trimaculatus and $S$. strigiventer utilized various substrates as habitat and may not need to move long distances over the tidal cycle.

Many herbivorous fish were also documented at increased densities with depth, as well as during flood tides. We found that all herbivores showed higher densities at $\mathrm{W}$ and $\mathrm{N}$, while most were almost absent at $\mathrm{L}$. The reason for this partitioning may not only be related to depth, but also to food sources. Most herbivores fed mainly on filamentous epiphytes, which were more abundant on seagrass leaves of $\mathrm{W}$ and $\mathrm{N}$. We only observed two fish species (L. vaigiensis and $H$. far) to feed on seagrass as 
their main food source at the Dongsha Island. Although seagrasses are important primary producers in their namesake ecosystems, their cellulose-rich and low nutrientvalue tissues are considered a poor-quality food source for grazers (Thayer et al. 1984; Heck and Valentine 2006). Some parrotfish can directly feed on seagrass and are important grazers in certain tropical seagrass beds (Kirsch et al. 2002; Unsworth et al. 2007b). L. vaigiensis is a common seagrass feeder in the Indo-Pacific (Unsworth et al. 2007b; Gullström et al. 2011), and they rely on high cover seagrass beds for both shelter and food (Gullström et al. 2011). Juvenile $L$. vaigiensis ( $\mathrm{TL}<6 \mathrm{~cm}$ ), in contrast, fed mainly on epiphytes, detritus, or small crustaceans. These ontogenetic dietary changes may be related to the development of digestive organs that may not have the ability to digest cellulose until a certain age/size (Kramer and Bryant 1995; Nakamura et al. 2003).

Most herbivorous fish were present in seagrass beds during both tides. However, S. spinus and $H$. far showed more transient usage patterns and were never present in intertidal seagrass beds during ebb tides. A previous study in Indonesia found that Siganus species were present at higher densities in deeper meadows (Pogoreutz et al. 2012). The transient movement of $H$. far into seagrass meadows was also observed in the Hoga Island, Indonesia (Unsworth et al. 2007a). We pose herein that these two species may need more space, since they usually feed in groups, and these additional space requirements may partially explain why their habitat usage patterns differed to those of other herbivorous fish.

Most fish mentioned above decreased in density during ebb tides at the intertidal stations (W and L). However, although the water depth at W also decreased during ebb tides, as at L, some deeper tidal creeks or burrows (depth, 0.3 to $1.0 \mathrm{~m}$ ) in these meadows maintained sufficient water volume for some fish inhabitance. Indeed, we did find many fish still residing within these shallow areas at $\mathrm{W}$ as long as there is space for them to move, while most of these fish were absent at $\mathrm{L}$ during ebb tides. We postulate that these refuges may serve as important temporary shelters for fish in intertidal zones when neighboring areas are exposed to the air. These fish may stay in these shallow water refuges during ebb tides in order to avoid predators. The water columns here may support sufficient volume for scarids, lethrinids, and lutjanids, but are too shallow for large piscivores, such as lemon sharks, which are the main predators of these fish; lemon sharks were absent in intertidal zones during ebb tides. Similar shallow water usage patterns were documented for L. fulviflamma in tropical seagrass beds of the Indian Ocean (Dorenbosch et al. 2004) across the tidal cycle. Moreover, for scarids, staying in these shallow refuges not only allows them to avoid predators but also permits them to forage on the more nutritionally-rich seagrass shoots that are found in these shallow areas (Lee et al. in review).

A minority of fish (Figure 4, Group B) showed a preference for shallower stations and ebb tides, including detritivorous mugilids, A. elymus, G. oyena, G. richardsonii, and small S. barracuda. The mugilids and A. elymus were found at high densities at L during ebb tides. Furthermore, we found that these two species mostly stayed near the water's surface and seldom moved into seagrass meadows. Their decreased presence during flood tides may also be due to predator avoidance. As mentioned above, numerous piscivores migrated into the shallows during flood tides, and mugilids and A. elymus were important food sources for these predators. These fish may thus change their habitats during the early period of flood tides to avoid predators. Other surface-dwelling fish such as Fundulus heteroclitus in salt marshes (Kimball and Able 2012) and Anableps anableps in mangroves (Brenner and Krumme 2007) also alter their habitat during flood tides. Moreover, the POM on which mugilids feed is typically derived from primary producers (Blay 1995; Lin et al. 2007). The nearshore water circulation at $\mathrm{L}$ was relatively low in this study due to the distance of the study station from the channel (Figure 1), and detritus from seagrass and littoral plants readily accumulated (Huang 2012), providing a significant food source for these detritivorous mugilids. A. elymus and G. oyena can also feed on detritus, suggesting that these fish may have sufficient food sources in the lagoon. We also found that $A$. elymus fed on some terrestrial insects, meaning not all of their food comes from seagrass meadows. The fact that these surface-dwelling fish do not appear to interact with or reside within seagrass meadows may explain why their behavior differed from that of the seagrass inhabiting fish species.

G. richardsonii and small S. barracuda were the only two predatory fish species that preferred intertidal seagrass beds of the Dongsha Island. These two species can adapt to life in shallow seagrass meadows even during ebb tides, possibly because of their slender bodies. They may have more opportunities to forage in the shallowest regions of these seagrass beds during times at which others carnivores leave. Unlike large piscivores, small $S$. barracuda remained in shallow seagrass beds of $\mathrm{L}$ and W during ebb tides. We even found small $S$. barracuda in the water column where depths were $<5 \mathrm{~cm}$ at L. In general, they became more active as they became larger. Larger S. barracuda were instead considered to be 'transient' seagrass fish because they preferred deeper stations during flood tides and so did not permanently reside in shallow seagrass beds. G. richardsonii is another carnivorous fish that preferred intertidal areas of the Dongsha Island. Although there were no significant density differences between tides for this species, we often 
found them foraging actively in intertidal areas during ebb tides. They even had the ability to forage in exposed seagrass beds (authors' personal observation). We therefore consider this species to have special adaptations for life in very shallow water of intertidal seagrass beds.

\section{Conclusions}

Our results documented differences in fish assemblage and trophic structure between tides in tropical seagrass beds. We consider that water depth may be responsible for these complex assemblage dynamics. Different trophic groups had distinct habitat usage patterns that were dependent upon tide-driven changes in water depth. The density of herbivores, large-sized carnivores, and piscivores, but not small-sized carnivores, increased during flood tides. In contrast, detritivores decreased in density during flood tides. This study offers new information for fish movements over tidal cycles in tropical seagrass beds and provides important knowledge for better understanding of seagrass ecosystems in the Indo-Pacific.

\section{Additional file}

Additional file 1: The density (mean individual number per $100 \mathrm{~m}^{2} \pm$ standard error) of 31 fish species for stomach contents analysis at each site ( $L$ for lagoon shore, $\mathrm{W}$ for west tidal flat, and $\mathrm{N}$ for north coast subtidal) at either the flood (F) or ebb (E) tide in the seagrass beds at the Dongsha Island.

\section{Competing interests}

All authors declare that they have no competing interests.

\section{Authors' contributions}

The research was carried out in collaboration among all authors. CLL and HJL designed the experiment design. CLL, YSH, and CYC participated in all field works. CLL carried out the stomach contents analysis. CLL and YSH participated in data analysis. CYC helped for identifying invertebrate species in stomach contents. CLL and HJL drafted the manuscript. All authors read and approved the final manuscript.

\section{Acknowledgements \\ This study was financially supported by the administrative bureau of the Dongsha Atoll National Park of Taiwan. The field sampling permissions during study periods were allowed by Marine National Park Headquarters of Taiwan. We appreciate the help of Xiao-Xun Dai and Jun-Ming Yei during the field studies, as well as the efforts of Dr. Anderson B. Mayfield in the English proofreading of the manuscript. We would also like to acknowledge Chia-Chang Kuo for the assistance with the stomach contents analysis.}

Received: 11 June 2014 Accepted: 13 August 2014

Published: 22 August 2014

\section{References}

Adams SM (1976) Feeding ecology of eelgrass fish communities. Trans Am Fish Soc 105:514-519

Anderson MJ (2001) A new method for non-parametric multivariate analysis of variance in ecology. Aust Ecol 26:32-46

Anderson MJ, Gorley RN, Clarke KR (2008) PERMANOVA + for PRIMER: Guide to Software and Statistical Methods. PRIMER-E, Plymouth, UK

Ayvazian SG, Deegan LA, Finn JT (1992) Comparison of habitat use by estuarine fish assemblages in the Acadian and Virginian zoogeographic provinces. Estuaries 15:368-383
Beck MW, Heck KL Jr, Able KW, Childers DL, Eggleston DB, Gillanders BM, Halpern B, Hays CG, Hoshino K, Minello TJ, Orth RJ, Sheridan PF, Weinstein MP (2001) The identification, conservation, and management of estuarine and marine nurseries for fish and invertebrates. BioScience 51:633-641

Bellwood DR, Hughes TP, Folke C, Nyström M (2004) Confronting the coral reef crisis. Nature 429:827-833

Berkström C, Jörgensen T, Hellström M (2013) Ecological connectivity and niche differentiation between two closely related fish species in the mangroveseagrass-coral reef continuum. Mar Ecol Prog Ser 477:201-215

Blay J (1995) Food and feeding habits of four species of juvenile mullet (Mugilidae) in a tidal lagoon in Ghana. J Fish Biol 46:134-141

Brenner M, Krumme U (2007) Tidal migration and patterns in feeding of the four-eyed fish Anableps anableps L. in a north Brazilian mangrove. J Fish Biol 70:406-427

Clarke KR, Gorley RN (2006) PRIMER v6: user manual/tutorial. PRIMER-E, Plymouth, UK

Clarke KR, Warwick RM (1994) Changes in marine communities: an approach to statistical analyses and interpretation. J Zool 166:323-335

Dorenbosch M, Verweij MC, Nagelkerken I, Jiddawi N, van der Velde G (2004) Homing and daytime tidal movements of juvenile snappers (Lutjanidae) between shallow-water nursery habitats in Zanzibar, western Indian Ocean. Environ Biol Fishes 70:203-209

Dorenbosch M, Grol MGG, Christianen MJA, Nagelkerken I, van der Velde G (2005) Indo-Pacific seagrass beds and mangroves contribute to fish density and diversity on adjacent coral reefs. Mar Ecol Prog Ser 302:63-76

Duffy JE (2006) Biodiversity and the functioning of seagrass ecosystems. Mar Ecol Prog Ser 311:233-250

Gibson RN (1988) Patterns of movement in intertidal fishes. In: Chelazzi G, Vanini M (eds) Behavioural Adaptions to Intertidal Life, NATO ASI Series Life Sciences vol 151. Plenum Press, London, pp 55-63

Gibson RN (2003) Go with the flow: tidal migration in marine animals. Hydrobiologia 503:153-161

Gullström M, Berkström C, Öhman MC, Bodin M, Dahlberg M (2011) Scaledependent patterns of variability of a grazing parrotfish (Leptoscarus vaigiensis) in a tropical seagrass-dominated seascape. Mar Biol 158:1483-1495

Heck KL Jr, Valentine JF (2006) Plant-herbivore interactions in seagrass meadows. J Exp Mar Biol Ecol 330:420-436

Hoeinghaus DJ, Layman CA, Arrington DA, Winemiller KO (2003) Spatiotemporal variation in fish assemblage structure in tropical floodplain creeks. Environ Biol Fish 67:379-387

Horinouchi M, Nakamura Y, Sano M (2005) Comparative analysis of visual censuses using different width strip-transects for a fish assemblage in a seagrass bed. Estuar Coast Shelf Sci 65:53-65

Huang YH (2012) The productivity and carbon budget of seagrass at Dongsha area. National Chung Hsing University, Taiwan, Master Thesis, pp 37-39

Hyslop EJ (1980) Stomach contents analysis: a review of methods and their application. J Fish Biol 17:411-429

Kamukuru AT, Mgaya YD (2004) The food and feeding habits of blackspot snapper, Lutjanus fulviflamma (Pisces: Lutjanidae) in shallow waters of Mafia Island, Tanzania. Afr J Ecol 42:49-58

Kimball ME, Able KW (2012) Tidal migrations of intertidal salt marsh creek nekton examined with underwater video. Northeast Nat 19:475-486

Kimirei IA, Nagelkerken I, Griffioen B, Wagner C, Mgaya YD (2011) Ontogenetic habitat use by mangrove/seagrass-associated coral reef fishes shows flexibility in time and space. Estuar Coast Shelf Sci 92:47-58

Kirsch KD, Valentine JF, Heck KL Jr (2002) Parrotfish grazing on turtlegrass Thalassia testudinum: evidence for the importance of seagrass consumption in food web dynamics of the Florida Keys National Marine Sanctuary. Mar Ecol Prog Ser 227:71-85

Klumpp DW, Nichols PD (1983) A study of food chains in seagrass communities. II. Food of the rock flathead, Platycephalus laevigatus Cuvier, a major predator in a Posidonia autralis seagrass bed. Mar Freshwater Res 34:745-754

Kneib RT, Wagner SL (1994) Nekton use of vegetated marsh habitats at different stages of tidal inundation. Mar Ecol Prog Ser 106:227-238

Kramer DL, Bryant MJ (1995) Intestine length in the fishes of a tropical stream: 2 Relationships to diet-the long and short of a convoluted issue. Environ Biol Fish 42:129-141

Krumme $U$ (2004) Pattern in the tidal migration of fish in a north Brazilian mangrove channel as revealed by a vertical split-beam echosounder. Fish Res 70:1-15

Krumme U (2009) Diel and tidal movements by fish and decapods linking tropical coastal ecosystems. In: Nagelkerken I (ed) Ecological Connectivity among Tropical Coastal Ecosystems. Springer, Netherlands, pp 271-324 
Krumme U, Brenner M, Saint-Paul U (2008) Spring-neap cycle as a major driver of temporal variations in feeding of intertidal fishes: evidence from the sea catfish Sciades herzbergii (Ariidae) of equatorial west Atlantic mangrove creeks. J Exp Mar Biol Ecol 367:91-99

Last PR, Stevens JD (2009) Sharks and Rays of Australia (Second Edition). CSIRO, Collingwood, Australia

Lin HJ, Hsieh LY, Liu PJ (2005) Seagrasses of Tongsha Island, with descriptions of four new records to Taiwan. Bot Bull Acad Sinica 46:163-168

Lin HJ, Kao WY, Wang YT (2007) Analyses of stomach contents and stable isotopes reveal food sources of estuarine detritivorous fish in tropical/ subtropical Taiwan. Estuar Coast Shelf Sci 73:527-537

Lugendo BR, Nagelkerken I, van der Velde G, Mgaya YD (2006) The importance of mangroves, mud and sand flats, and seagrass beds as feeding areas for juvenile fishes in Chwaka Bay, Zanzibar: gut content and stable isotope analyses. J Fish Biol 69:1639-1661

Nagelkerken I (2009) Evaluation of nursery function of mangroves and seagrass beds for tropical decapods and reef fishes: and underlying mechanisms. In: Nagelkerken I (ed) Ecological Connectivity among Tropical Coastal Ecosystems. Springer, Netherlands, pp 357-399

Nagelkerken I, van der Velde G (2004) Relative importance of interlinked mangroves and seagrass beds as feeding habitats for juvenile reef fish on a Caribbean island. Mar Ecol Prog Ser 274:153-159

Nagelkerken I, van der Velde G, Verberk WCEP, Dorenbosch M (2006) Segregation along multiple resource axes in a tropical seagrass fish community. Mar Ecol Prog Ser 308:79-89

Nakamura Y, Horinouchi M, Nakai T, Sano M (2003) Food habits of fishes in a seagrass bed on a fringing coral reef at Iriomote Island, southern Japan. Ichthyol Res 50:15-22

Nakamura Y, Shibuno T, Suzuki N, Nakamori J, Kanashiro K, Watanabe Y (2010) Interspecific variations in age and size at settlement of 8 emperor fishes (Lethrinidae) at the southern Ryukyu Islands, Japan. Fisheries Sci 76:503-510

Nakamura Y, Hirota K, Shibuno T, Watanabe Y (2012) Variability in nursery function of tropical seagrass beds during fish ontogeny: timing of ontogenetic habitat shift. Mar Biol 159:1305-1315

Parrish JD (1989) Fish communities of interacting shallow-water habitats in tropical oceanic regions. Mar Ecol Prog Ser 58:143-160

Pogoreutz C, Kneer D, Litaay M, Asmus H, Ahnelt H (2012) The influence of canopy structure and tidal level on fish assemblages in tropical Southeast Asian seagrass meadows. Estuar Coast Shelf Sci 107:58-68

R Development Core Team (2012) R: A Language and Environment for Statistical Computing. R Foundation for Statistical Computing, Vienna, Austria, URL http://www.R-project.org/. ISBN 3-900051-07-0

Reis-Filho JA, Barros F, Nunes JDACDC, Sampaio CLS, De Souza GBG (2011) Moon and tide effects on fish capture in a tropical tidal flat. J Mar Biol Ass UK 91:735-743

Robertson Al, Duke NC (1990) Mangrove fish communities in tropical Australia: spatial and temporal patterns in densities, biomass and community structure. Mar Biol 104:369-379

Saito Y, Atobe S (1970) Phytosociological study of intertidal marine algae: I. usujiri benten-jima, Hokkaido. Bull Fish Sci Hokkaido Univ 21:37-69

Sogard SM, Powell GVN, Holmquist JG (1989) Utilization by fishes of shallow, seagrass-covered banks in Florida Bay: 2. Diel and tidal patterns. Environ Biol Fish 24:8-92

Thayer GW, Bjorndal KA, Odgen JC, Williams SL, Zieman JC (1984) Role of larger herbivores in seagrass communities. Estuaries 7:351-376

Unsworth RKF, Cullen LC (2010) Recognising the necessity for Indo-Pacific seagrass conservation. Conserv Lett 3:63-73

Unsworth RKF, Bell JJ, Smith DJ (2007a) Tidal fish connectivity of reef and seagrass habitats in the Indo-Pacific. J Mar Biol Ass UK 87:1287-1296

Unsworth RKF, Taylor JD, Powell A, Bell JJ, Smith DJ (2007b) The contribution of scarid herbivory to seagrass ecosystem dynamics in the Indo-Pacific. Estuar Coast Shelf Sci 74:53-62

Unsworth RKF, Salinas de León P, Garrard SL, Jompa J, Smith DJ, Bell JJ (2008a) High connectivity of Indo-Pacific seagrass fish assemblages with mangrove and coral reef habitats. Mar Ecol Prog Ser 353:213-224

Unsworth RKF, Salinas de León P, Garrard SL, Smith DJ, Bell JJ (2008b) Habitat usage of the Thumbprint Emporer Lethrinus harak (Forsskål, 1775) in an Indo-Pacific coastal seascape. Open Mar Biol J 2:59-63
Unsworth RKF, Garrard SL, Salinas de León P, Sloman KA, Cullen LC, Smith DJ, Bell JJ (2009) Structuring of Indo-Pacific fish assemblages along the mangrove-seagrass continuum. Aquat Biol 5:85-95

Vonk JA, Christianen MJA, Stapel J (2008) Redefining the trophic importance of seagrasses for fauna in tropical Indo-Pacific meadows. Estuar Coast Shelf Sci 79:653-660

Wilkinson L, Friendly M (2009) The history of the cluster heat map. Am Stat 63:179-184

doi:10.1186/s40555-014-0056-9

Cite this article as: Lee et al:: Tidal variation in fish assemblages and trophic structures in tropical Indo-Pacific seagrass beds. Zoological Studies 2014 53:56.

\section{Submit your manuscript to a SpringerOpen ${ }^{\odot}$ journal and benefit from:}

- Convenient online submission

Rigorous peer review

- Immediate publication on acceptance

- Open access: articles freely available online

- High visibility within the field

- Retaining the copyright to your article

Submit your next manuscript at $\boldsymbol{s p r i n g e r o p e n . c o m ~}$ 